\title{
MicroRNA profiles in cisplatin-induced apoptosis of hepatocellular carcinoma cells
}

\author{
MIWA MIYATA $^{1}$, ASAHIRO MORISHITA ${ }^{1}$, TEPPEI SAKAMOTO ${ }^{1}$, AKIKO KATSURA $^{1}$, \\ KIYOHITO KATO $^{1}$, TOMOKO NISHIOKA ${ }^{1}$, YUKA TOYOTA ${ }^{1}$, KOJI FUJITA ${ }^{1}$, EMIKO MAEDA ${ }^{1}$, \\ TAKAKO NOMURA ${ }^{1}$, JOJI TANI ${ }^{1}$, HISAAKI MIYOSHI ${ }^{1}$, HIROHITO YONEYAMA $^{1}$, \\ HIDEKI KOBARA ${ }^{1}$, SHINTARO FUJIWARA ${ }^{1}$, NORIKO NISHIYAMA ${ }^{1}$, HISAKAZU IWAMA ${ }^{2}$, \\ TAKASHI HIMOTO ${ }^{3}$, MITSUOMI HIRASHIMA ${ }^{1}$ and TSUTOMU MASAKI $^{1}$
}

\author{
${ }^{1}$ Department of Gastroenterology and Neurology and ${ }^{2}$ Life Science Research Center, Kagawa University Faculty of Medicine, \\ Miki-cho, Kita-gun, Kagawa 761-0793; ${ }^{3}$ Department of Medical Technology, Kagawa Prefectural University \\ of Health Sciences, Mure-cho, Takamatsu, Kagawa 761-0123, Japan
}

Received March 17, 2015; Accepted April 27, 2015

DOI: $10.3892 / \mathrm{ijo} .2015 .3036$

\begin{abstract}
Cisplatin [cis-diamminedichloroplatinum (II)], is a platinum coordination compound that is commonly used to treat hepatocellular carcinoma (HCC). It is also one of the most compelling anticancer drugs. Recent studies suggest that cisplatin may reduce cancer risk and improve prognosis. However, the antitumor mechanism of cisplatin in several types of cancers, including HCC, has not been elucidated. The goal of the present study was to evaluate the effects of cisplatin on the proliferation of HCC cells in vitro and to determine which microRNAs (miRNAs) are associated with the anticancer effects of cisplatin in vitro. We used various human HCC-derived cell lines to study the effects of cisplatin on human HCC cells. Cisplatin led to a strong dose- and time- dependent inhibition of cell proliferation in HLE, HLF, HuH7, Li-7, Hep3B and HepG2 cells in vitro. Cisplatin also blocked the progression of the cell cycle in the $\mathrm{G} 0 / \mathrm{G} 1$ phase, which inhibited cyclin D1 and induced apoptosis. In addition, miRNA expression was markedly altered by treatment with cisplatin in vitro. Therefore, various miRNAs induced by cisplatin may also contribute to the suppression of cellular proliferation and apoptosis. Our results demonstrate that cisplatin inhibits the growth of HCC, possibly through the induction of G1 cell cycle arrest and apoptosis through the alteration of microRNA expression.
\end{abstract}

Correspondence to: Dr Tsutomu Masaki, Department of Gastroenterology and Neurology, Kagawa University School of Medicine, 1750-1 Ikenobe, Miki-cho, Kita-gun, Kagawa 761-0793, Japan E-mail: tmasaki@med.kagawa-u.ac.jp

Key words: microRNA, cisplatin, apoptosis, hepatocellular carcinoma, cell cycle

\section{Introduction}

Liver cancer is the third most common cause of cancer death worldwide and an estimated 696,000 deaths from liver cancer occurred in 2008 (1). Surgery is currently the most effective treatment for patients with hepatocellular carcinoma (HCC) (2). However, the indication of surgery is restricted by limited criteria $(2,3)$. In addition, although the survival rate has improved during the past decade, the rate of recurrence after surgery still remains high in patients with HCC (4). Therefore, systemic chemotherapy is required for patients with advanced stages of HCC in order to prolong their survival.

Cisplatin [cis-diamminedichloroplatinum (II)] is a commonly used anticancer drug, the biological activity of which was first reported in 1965 (5). Cisplatin exerts cytotoxic effects primarily by an interaction with cellular DNA; its binding alters the structure of DNA and affects its ability to act as a template during transcription, which ultimately triggers apoptotic cell death $(6,7)$. Despite a stable rate of initial responses, cisplatin treatment often results in therapeutic failure due to the development of chemoresistance (6). Several mechanisms related to the cisplatin-induced antitumor effects have been reported in the past several decades. Apoptosis is one of the major components of cisplatin-induced cytotoxicity (8). With respect to the relationship between the cytotoxic effects of cisplatin and the aberrant expression of microRNAs (miRNAs), several studies have identified the presence of dysregulated miRNAs in various cancers, such as breast, gastric, lung, esophageal, ovarian, and tongue cancers (9). However, the mechanism involved in the relationship between cisplatin and $\mathrm{HCC}$ remains elusive.

miRNAs are essentially 18-22 nucleotide-long endogenous noncoding RNAs $(3,10)$. The effect of miRNAs on the regulation of the expression of various genes is so broad that one miRNA controls more than 200 genes (11). Among various human cancers, it has been reported that aberrant expression of miRNAs is a common feature and is related to patient survival (12-15). In addition, with regard to the relationship 
between miRNAs and HCC, several studies have shown aberrant expression of specific miRNAs in HCC tissues compared with normal tissues (16-19). These previous studies indicate that the modulation of non-coding RNAs, especially miRNAs, might be a valuable target for HCC formation.

Therefore, in our present study, we intended to elucidate the profiles of miRNAs that are associated with the cisplatininduced antitumor effects observed in HCC cell lines, as well as the role of cell cycle regulatory molecules and apoptosisrelated caspase proteins. An analysis of the miRNA profiles after treatment with cisplatin may be a novel approach for the treatment of patients with cisplatin-resistant HCC.

\section{Materials and methods}

Chemicals. Cisplatin was purchased from Nippon Kayaku (Tokyo, Japan). A Cell Counting kit (CCK-8) was purchased from Dojindo Laboratories (Kumamoto, Japan), and all other chemicals were obtained from Sigma Chemical (Tokyo, Japan).

Antibodies. In this study, the following antibodies were used: anti- $\beta$-actin monoclonal antibody (Sigma-Aldrich, St. Louis, MO, USA; A5441, used at 1:2,000), cyclin D1 (Thermo Fisher Scientific, Waltham, MA, USA; RB-9041, used at 1:1,000), Cdk6 (Santa Cruz Biotechnology, Santa Cruz, CA, USA; sc-177, used at 1:500), Cdk4 (Cell Signaling Technology, Danvers, MA, USA; \#2906, used at 1:1,000), horseradish peroxidase (HRP)-linked anti-mouse and anti-rabbit $\operatorname{IgG}$ secondary antibodies (GE Healthcare UK, Buckinghamshire, UK; used at 1:2,000).

Cell lines and culture. The human hepatocellular carcinoma cell lines HLE, HLF, HuH7, Li-7, Hep3B and HepG2 were obtained from the Japanese Cancer Research Resources Bank and were passaged in our laboratory. The cell lines were authenticated by the cell bank using short tandem repeat PCR. Cells were grown in Minimum Essential Medium (MEM) (Gibco Invitrogen, Carlsbad, CA, USA) supplemented with 10\% FBS (533-69545; Wako) and penicillin-streptomycin $\left(100 \mathrm{mg} / \mathrm{l}\right.$; Invitrogen) in a humidified atmosphere of $5 \% \mathrm{CO}_{2}$ at $37^{\circ} \mathrm{C}$.

Cell proliferation assay. Cell proliferation assays were conducted using the CCK- 8 according to the manufacturer's instructions. Cells from each cell line $\left(0.5 \times 10^{4}\right)$ were seeded into a 96-well plate and cultured in $100 \mu 1$ of MEM supplemented with $10 \%$ FBS. After $24 \mathrm{~h}$, the seeded cells were treated with $0,1,3$ or $10 \mu \mathrm{g} / \mathrm{ml}$ of cisplatin added to the culture medium. At the indicated time points, the medium was changed to $100 \mu \mathrm{l}$ of MEM with CCK-8 reagent (10 $\mu \mathrm{l}$ of CCK- 8 and $90 \mu \mathrm{l}$ of MEM). Absorbance was measured for each well at a wavelength of $450 \mathrm{~nm}$ using an auto-microplate reader.

Cell lysates. The lysates were collected according to the methods described in our previous studies (20). All steps were performed at $4^{\circ} \mathrm{C}$. Protein concentrations were measured using a dye-binding protein assay based on the Bradford method (21).

Gel electrophoresis and western blotting. Samples were electrophoresed using 7.5 to $10 \%$ SDS-PAGE (22) after which the proteins were transferred to nitrocellulose membranes. The membranes were incubated with primary antibodies after blocking and were then incubated with HRP-conjugated secondary antibodies (23). Immunoreactive proteins were visualized with an enhanced chemiluminescence detection system (Perkin Elmer Co.) on X-ray film.

Apoptosis. The detection of caspase-cleaved cytokeratin 18 (CK18) was performed using an M30 Apoptosense ELISA kit which was purchased from Peviva AB (Bromma, Sweden). $\mathrm{HuH} 7$ cells $\left(0.5 \times 10^{4}\right)$ were seeded into a 96 -well plate and cultured in $100 \mu 1$ of MEM supplemented with $10 \%$ FBS. After $24 \mathrm{~h}$, the seeded cells were washed once with PBS and treated with $1 \mu \mathrm{g} / \mathrm{ml}$ of cisplatin added to the culture medium. At the indicated time points, $10 \mu 1$ of PRO-PREP ${ }^{\mathrm{TM}}$ protein extraction solution was added to each well. The plates were shaken on a rotary shaker for $5 \mathrm{~min}$ at room temperature in order to lyse the cells. Next, $25 \mu$ l of M30 Standard (A-G), M30 Control Low, M30 Control High or samples was pipetted into the appropriate wells. A total of $75 \mu 1$ of the diluted M30 HRP Conjugate solution was also added to each well. The cells were incubated at room temperature for $4 \mathrm{~h}$. The incubation solution was discarded, and the plate was washed five times with $250 \mu \mathrm{l}$ of diluted washing solution. Next, $200 \mu \mathrm{l}$ of TMB substrate was added to each well. The cells were incubated in the dark at room temperature for $20 \mathrm{~min}$. Then, $50 \mu \mathrm{l}$ of stop solution was added to each well. After $5 \mathrm{~min}$, the absorbance was measured at a wavelength of $450 \mathrm{~nm}$ using an auto-microplate reader.

Antibody arrays of phosphorylated receptor tyrosine kinase. The RayBio Human Phospho Array kit (catalog no. ARY 001) was purchased from RayBiotech, Inc (Norcross, GA, USA). An array to detect phosphorylated receptor tyrosine kinase (p-RTK) was conducted according to the manufacturer's instructions. Briefly, p-RTK array membranes were blocked with $5 \%$ bovine serum albumin (BSA)/TBS $(0.01 \mathrm{~mol} / 1$ Tris-HCl, $\mathrm{pH}$ 7.6) for $1 \mathrm{~h}$. The membranes were then incubated with $1.5 \mathrm{ml}$ of lysate prepared from cell lines after normalization with equal amounts of protein. After extensive washing with TBS containing $0.1 \%$ v/v Tween-20 ( 3 washes for $10 \mathrm{~min}$ each), the membranes were then incubated with an anti-phospho-tyrosine-HRP detection antibody for $2 \mathrm{~h}$ at room temperature. The unbound HRP antibody was washed away with TBS with $0.1 \%$ Tween-20. Finally, each array membrane was exposed to X-ray film using a chemiluminescence detection system (Perkin Elmer Co.). The density of the immunoreactive band obtained on the p-RTK array was analyzed by densitometric scanning (Tlc scanner, Shimizu Co., Ltd.).

Angiogenic profile analysis using an antibody array. The RayBio Human Angiogenesis Antibody Array 1 kit (catalog no. AAH-ANG-1) was purchased from RayBiotech, Inc. The assay for the antibody array was performed according to the manufacturer's instructions. Briefly, the angiogenesis antibody membranes were blocked with blocking buffer for $30 \mathrm{~min}$. The membranes were then incubated with $1 \mathrm{ml}$ of lysate prepared from the cell lines after normalization with equal amounts of protein. After extensive washing with TBS with $0.1 \% \mathrm{v} / \mathrm{v}$ Tween-20 (3 washes for 5 min each) and with TBS alone ( 2 washes for $5 \mathrm{~min}$ each) to remove unbound lysate, 
HLE

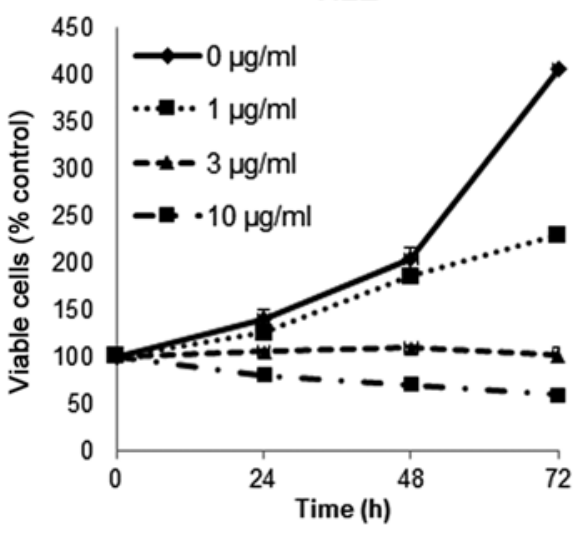

Li-7

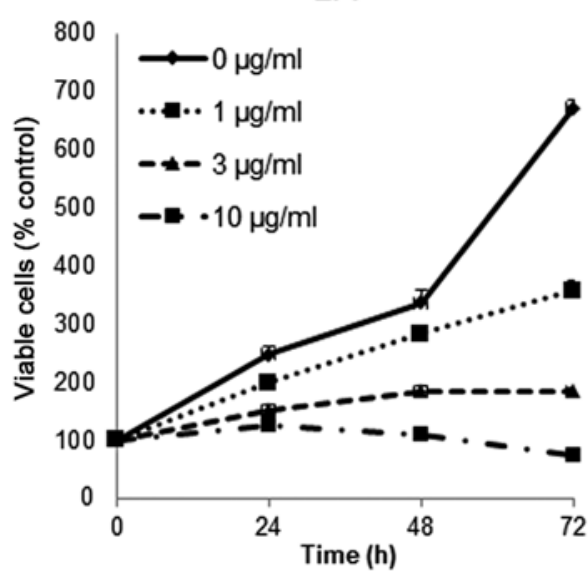

HLF

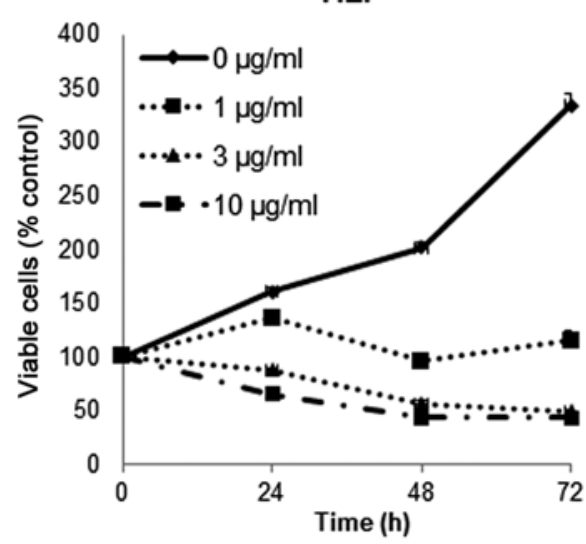

Hep3B

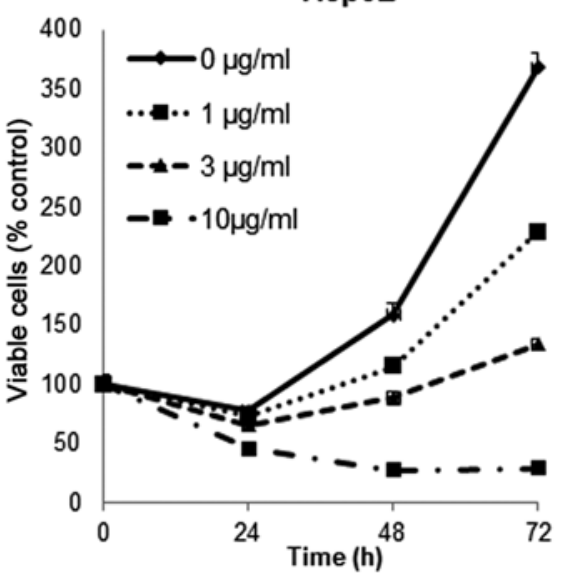

HuH7

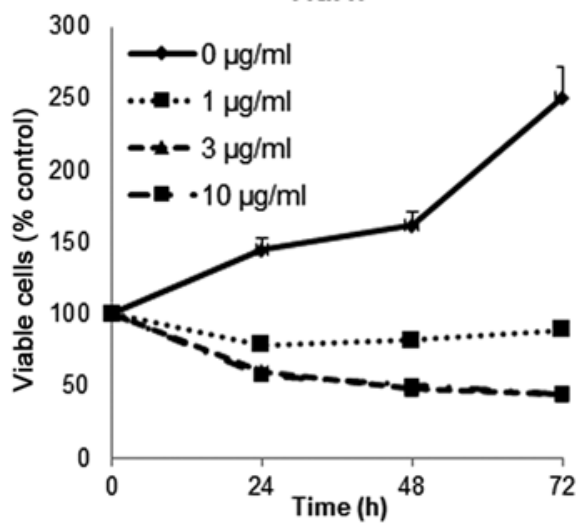

HepG2

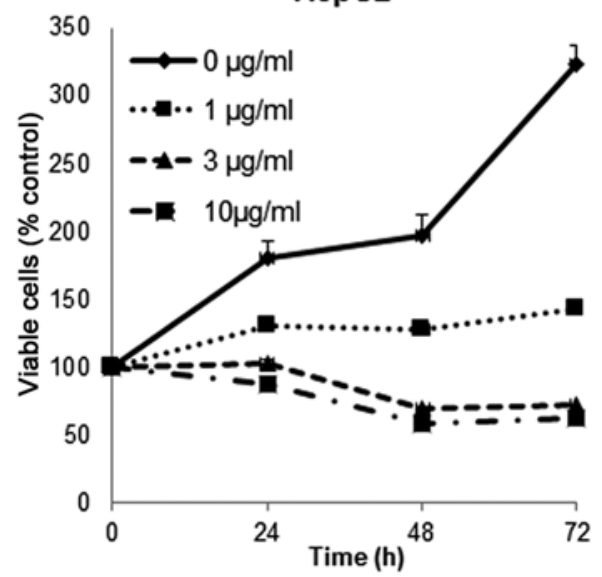

Figure 1. Cisplatin inhibits the proliferation of various hepatocellular carcinoma cells in culture. The number of viable cells that were treated with cisplatin $(1,3,10 \mu \mathrm{g} / \mathrm{ml})$ was significantly decreased compared with the number of viable control cells at both 48 and $72 \mathrm{~h}$. The data points represent the mean cell number from three independent cultures, and the error bars represent the SDs.

the membranes were then incubated with biotin-conjugated antibodies for $1 \mathrm{~h}$ at room temperature. After washing the membranes with TBS with $0.1 \%$ Tween-20 and with TBS alone, the membranes were incubated with HRP-conjugated streptavidin for $2 \mathrm{~h}$ at room temperature. After washing these membranes, finally, each array membrane was exposed to X-ray film using a chemiluminescence detection system (Perkin Elmer Co.). The density of the immunoreactive band obtained on this array was analyzed by densitometric scanning (Tlc scanner, Shimizu Co., Ltd.).

Analysis of the microRNA array. Total RNA was extracted from the samples derived from the cancer cell lines using a miRNeasy Mini kit (Qiagen, Hilden, Germany) according to the manufacturer's instructions. RNA samples typically showed $\mathrm{A}_{260 / 280}$ ratios between 1.9 and 2.1, using an Agilent 2100 Bioanalyzer (Agilent Technologies, Santa Clara, CA, USA).

After measurement of the RNA with an RNA 6000 Nano kit (Agilent Technologies), the samples were labeled using a miRCURY Hy3/Hy5 power labeling kit and were hybridized onto a human miRNA Oligo chip (version 19.0; Toray Industries, Tokyo, Japan). Scanning was conducted with the 3D-Gene Scanner 3000 (Toray Industries), and 3D-Gene extraction version 1.2 software (Toray Industries) was used to read the raw intensity of the image. To determine the change in miRNA expression between the cisplatin-treated samples and the control samples, the raw data were analyzed via GeneSpringGX version 10.0 (Agilent Technologies). Samples were first normalized relative to the $28 \mathrm{~S}$ RNA, and then the baseline was corrected to the median of all samples.

Replicate data were consolidated into two groups: those from the cisplatin-treated cells and those from the control cells were organized by the hierarchical clustering and ANOVA functions in GeneSpring software. Hierarchical clustering was performed with the clustering function (condition tree) and Euclidean correlation as a distance metric. Two-way ANOVA analysis and asymptotic p-value computation without any error correction of the samples were conducted to determine the miRNAs that varied most prominently across the different groups. The p-value cutoff was set to 0.05 . Only changes $>50 \%$ in at least one of the time points for each sample were considered significant. All of the analyzed data were scaled by global normalization. The statistical significance of the differentially expressed miRNAs was analyzed by Student's t-test.

Statistical analysis. All analyses were conducted using the computer-assisted JMP8.0 (SAS Institute, Cary, NC, USA). A paired analysis between the groups was conducted using Student's t-test. A p-value of 0.05 indicated a significant difference between the groups. 
A

\begin{tabular}{|c|c|c|c|c|c|c|c|c|c|c|c|}
\hline $\begin{array}{c}\text { PY- } \\
\text { control }\end{array}$ & & & & & & & & & & & $\begin{array}{c}\text { PY- } \\
\text { control }\end{array}$ \\
\hline EGFR & ErbB2 & ErbB3 & ErbB4 & FGFR1 & FGFR2a & FGFR3 & FGFR4 & InsulinR & IGF-1R & Axl & Dtk \\
\hline Mer & HGFR & MSPR & PDGFRa & PDGFR3 & SCFR & Flt-3 & M-CSFR & c-Ret & ROR1 & ROR2 & Tie-1 \\
\hline Tie-2 & TrkA & TrkB & TrkC & VEGFR1 & VEGFR2 & VEGFR3 & MuSK & EphA1 & EphA2 & EphA3 & EphA4 \\
\hline EphA6 & EphA7 & EphB1 & EphB2 & EphB4 & EphB6 & $\begin{array}{c}\text { Mouse } \\
\text { IgG1 }\end{array}$ & $\begin{array}{c}\text { Mouse } \\
\text { IgG2A }\end{array}$ & $\begin{array}{c}\text { Mouse } \\
\text { IgG2B }\end{array}$ & $\begin{array}{c}\text { Goat } \\
\text { IgG }\end{array}$ & PBS & \\
\hline $\begin{array}{c}\text { PY- } \\
\text { control }\end{array}$ & & & & & & & & & & & $\begin{array}{c}\text { PY- } \\
\text { control }\end{array}$ \\
\hline
\end{tabular}

PY-control:Phospho tyrosine positive control

B

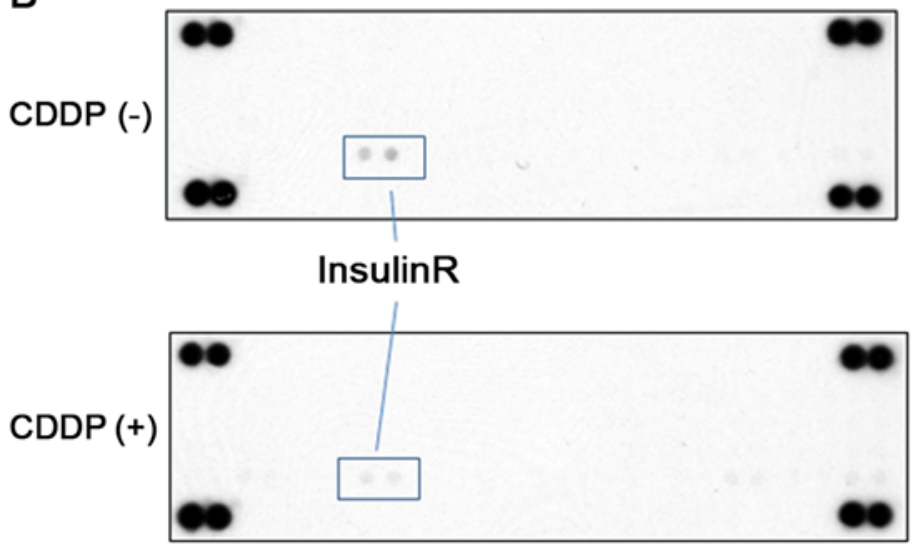

C

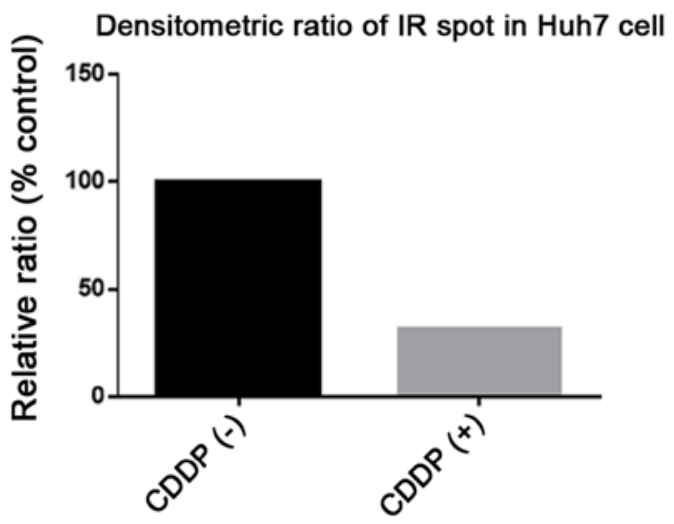

Figure 2. (A) Template showing the location of tyrosine kinase antibody spotted onto the RayBio Human Phospho Array kit. (B) The representative expression of various p-RTKs in HuH7 cells with or without cisplatin treatment. Reduced expression of IR was detected in cisplatin-treated Huh7 cells. (C) The densitometric ratio of the insulin receptor spots of the cisplatin-treated $\mathrm{HuH7}$ cells to the non-treated cells was $31.2 \%$.

\section{Results}

Cisplatin inhibits the proliferation of human HCC cells. To evaluate the effect on the growth activity of human HCC cell lines by cisplatin in vitro, we examined the effect of cisplatin on the proliferation of six human HCC cell lines: HLE, HLF, HuH7, Li-7, Hep3B and HepG2. To understand the direct relationship between the decrease in cell viability and the inhibition of cell proliferation, we followed the course of proliferation over three days after the addition of cisplatin. Cells were grown in culture medium and treated with 0,1 , 3 or $10 \mu \mathrm{g} / \mathrm{ml}$ of cisplatin. As shown in Fig. 1, cisplatin led to a strong dose- and time-dependent inhibition of cell proliferation in the human HCC cell lines HLE, HLF, HuH7, Li-7, Hep3B and HepG2. These results show that cisplatin inhibits the proliferation of human HCC cells.

Differences in phosphorylated receptor tyrosine kinases (p-RTKs) in HuH7 cells with or without cisplatin treatment in vitro. After the antitumor effects of cisplatin in human $\mathrm{HCC}$ cell lines were established, we next used a phosphorylated-RTK array system to identify the 'key' RTKs that are responsible for these antitumor effects. With an antibody array (Fig. 2A), we simultaneously screened the expression of 42 different RTKs in $\mathrm{HuH} 7$ cells with or without cisplatin treatment. The results showed that the expression of insulin receptor (Insulin R) (Fig. 2B) was reduced by the treatment with cisplatin.

The density of the Insulin R obtained from the membrane array was analyzed by a Kodak Image Station (Eastman
Kodak, Rochester, NY, USA). The densitometric ratio of the Insulin R spots of the cisplatin-treated cell lines to the Insulin $\mathrm{R}$ spots of the untreated cell lines was reduced to $31.2 \%$ (Fig. 2C).

Differences in the expression of angiogenesis-related protein in $\mathrm{HuH7}$ cells with or without cisplatin treatment in vitro. We used an angiogenesis antibody array system to identify the 'key' angiogenesis-related proteins responsible for the antitumor effects of cisplatin. By using this antibody array (Fig. 3A), we simultaneously screened the expression of 20 different angiogenesis markers in the human HCC cell line $\mathrm{HuH} 7$ with or without cisplatin treatment. None of the markers of angiogenesis were changed by treatment with cisplatin as detected by the protein array (Fig. 3B).

Effects of cisplatin on cell cycle regulatory proteins in $\mathrm{HuH7}$ cells. To determine whether cisplatin affects the cell cycle in $\mathrm{HuH} 7$ cells, western blot analysis was used to examine the expression of various cell cycle-related molecules in $\mathrm{HuH} 7$ cells with and without cisplatin treatment. Cells were treated with $1 \mu \mathrm{g} / \mathrm{ml}$ of cisplatin or were left untreated for $24-72 \mathrm{~h}$. The most remarkable change was the loss of cyclin D1, a key protein that has been implicated in the G0/G1 transition (Fig. 4). We then studied the expression of other cell cycle-related proteins (Cdk4 and Cdk6) that have also been implicated in the G0/G1 transition. Cdk4 and Cdk6, the catalytic subunits of cyclin D1, were not changed after the addition of cisplatin to the culture medium. The amount of $\beta$-actin (an internal control for protein 
A

\begin{tabular}{|c|c|c|c|c|c|c|c|}
\hline POS & POS & NEG & NEG & Angiogenin & EGF & ENA-78 & bFGF \\
\hline POS & POS & NEG & NEG & Angiogenin & EGF & ENA-78 & bFGF \\
\hline GRO & IFN-Y & IGF-1 & IL-6 & IL-8 & LEPTIN & MCP-1 & PDGF-BB \\
\hline GRO & IFN-Y & IGF-1 & IL-6 & IL-8 & LEPTIN & MCP-1 & PDGF-BB \\
\hline PIGF & RANTES & TGF- $\beta 1$ & TIMP-1 & TIMP-2 & $\begin{array}{c}\text { Thrombo } \\
\text { poietin }\end{array}$ & VEGF & VEGF-D \\
\hline PIGF & RANTES & TGF- $\beta 1$ & TIMP-1 & TIMP-2 & $\begin{array}{c}\text { Thrombo } \\
\text { poietin }\end{array}$ & VEGF & VEGF-D \\
\hline BLANK & BLANK & BLANK & BLANK & BLANK & BLANK & Neg & POS \\
\hline BLANK & BLANK & BLANK & BLANK & BLANK & BLANK & Neg & POS \\
\hline
\end{tabular}

B
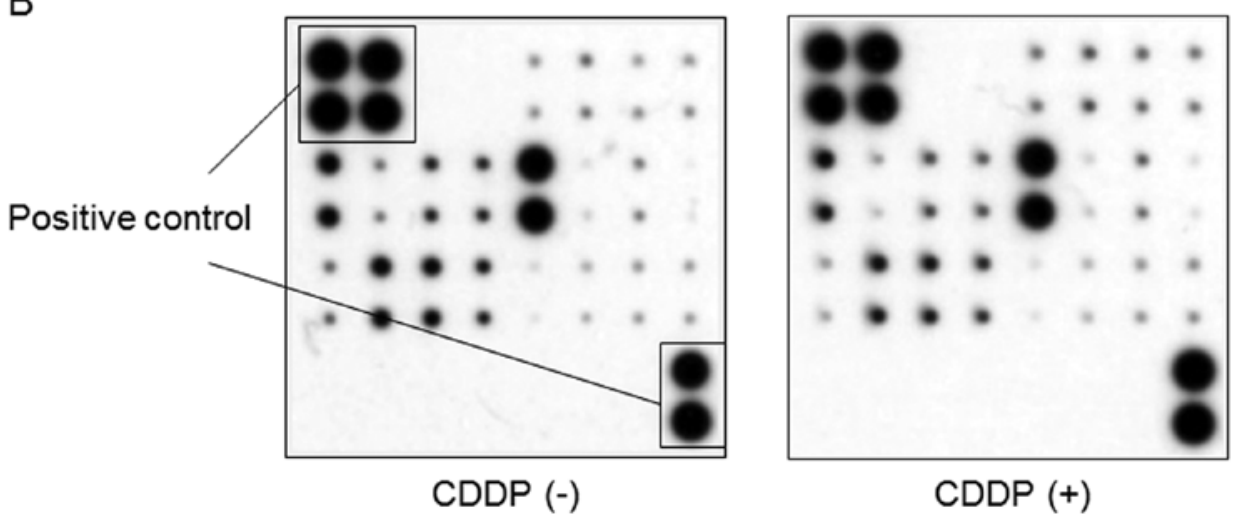

Figure 3. (A) Template showing the location of antibodies for angiogenesis-related protein spotted onto the Ray Bio Human Cytokine Antibody Array kit. (B) The representative expression of various angiogenic molecules in $\mathrm{HuH7}$ cells with or without cisplatin treatment. No induction of angiogenesis was detected in cisplatin-treated cells.

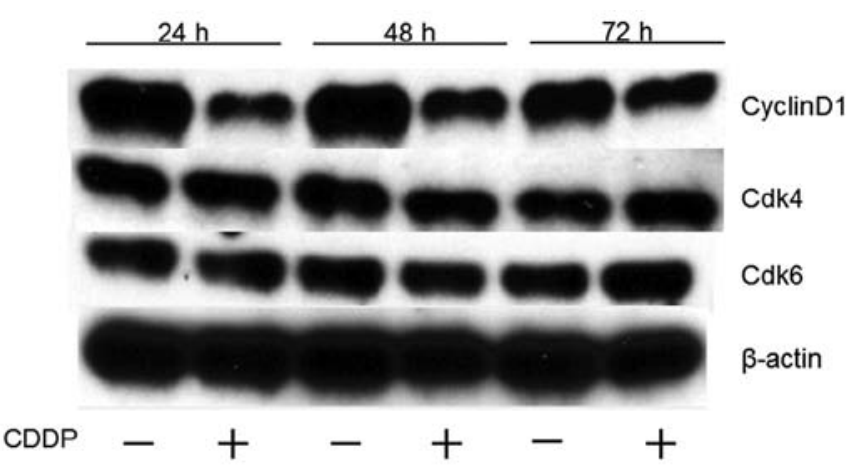

Figure 4. Western blot analysis of cyclin D1, Cdk4 and Cdk6 at the indicated time points $(24,48$ and $72 \mathrm{~h})$ after the addition of $1 \mu \mathrm{g} / \mathrm{ml}$ of cisplatin to the culture medium of $\mathrm{HuH} 7$ cells. Note that the expression of cyclin D1 was dramatically reduced in the $\mathrm{HuH} 7$ cells that were treated with cisplatin.

loading) was almost the same in each lane in sodium dodecyl sulfate polyacrylamide gel electrophoresis (Fig. 4).

Cisplatin induces apoptosis of $\mathrm{HuH7}$ cells. In order to establish that cisplatin induces apoptosis in HuH7 cells, we used the M30 Apoptosense method which specifically measures caspase-cleaved cytokeratin 18 in apoptotic cells. The activity in this assay is inhibited by a pan-caspase inhibitor. The M30 Apoptosense method is a useful screening tool as it measures the accumulation of the apoptotic product in cell cultures, which allows for an integrative determination of apoptosis until the cells are harvested. Cisplatin induced strong expression of caspase-cleaved cytokeratin-18 in $\mathrm{HuH} 7$ cells after $48 \mathrm{~h}$ of treatment (Fig. 5).

Differences in miRNA expression in $\mathrm{HuH7}$ cells with or without cisplatin treatment in vitro. Using a custom microarray platform, we analyzed the expression levels of 2019 human miRNAs in $\mathrm{HuH7}$ cells with or without cisplatin treatment in vitro. As shown in Fig. 6, Tables I and II, when the expression of miRNAs was examined in $\mathrm{HuH} 7$ cells treated with $1 \mu \mathrm{g} / \mathrm{ml}$ of cisplatin in vitro and in those not treated with cisplatin, 36 miRNAs were significantly upregulated (Table I) in $\mathrm{HuH} 7$ cells after $24 \mathrm{~h}$ of cisplatin treatment, while 10 miRNAs were downregulated (Table II) out of the 2019 total miRNAs. Unsupervised hierarchical clustering analysis, with Pearson's correlation, showed that $\mathrm{HuH7}$ cells treated with cisplatin clustered together and separately from the untreated cells (Fig. 6).

\section{Discussion}

Herein we present evidence for the reduction of a phosphorylated RTK (p-RTK), the IR, the downregulation of cyclin D1 among cell cycle regulatory molecules, and the miRNA profiles in HCC cells after treatment with cisplatin. 

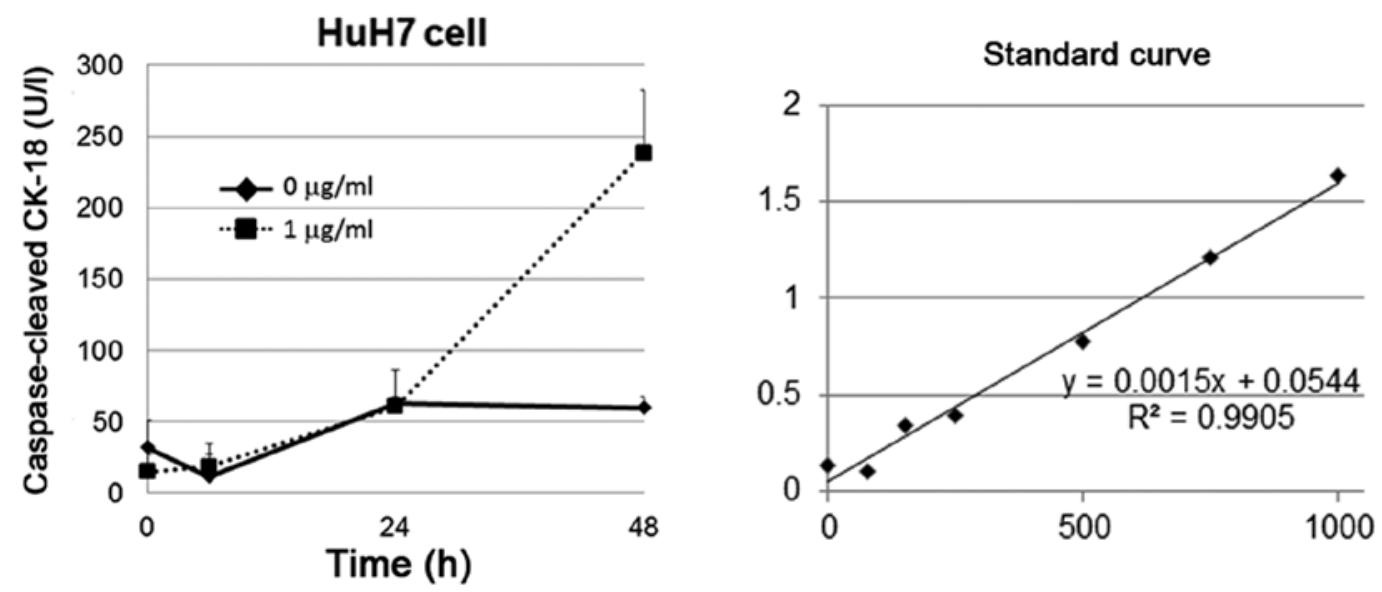

Figure 5. Cisplatin induced strong expression of caspase-cleaved cytokeratin-18 in $\mathrm{HuH} 7$ cells $48 \mathrm{~h}$ after cisplatin treatment.

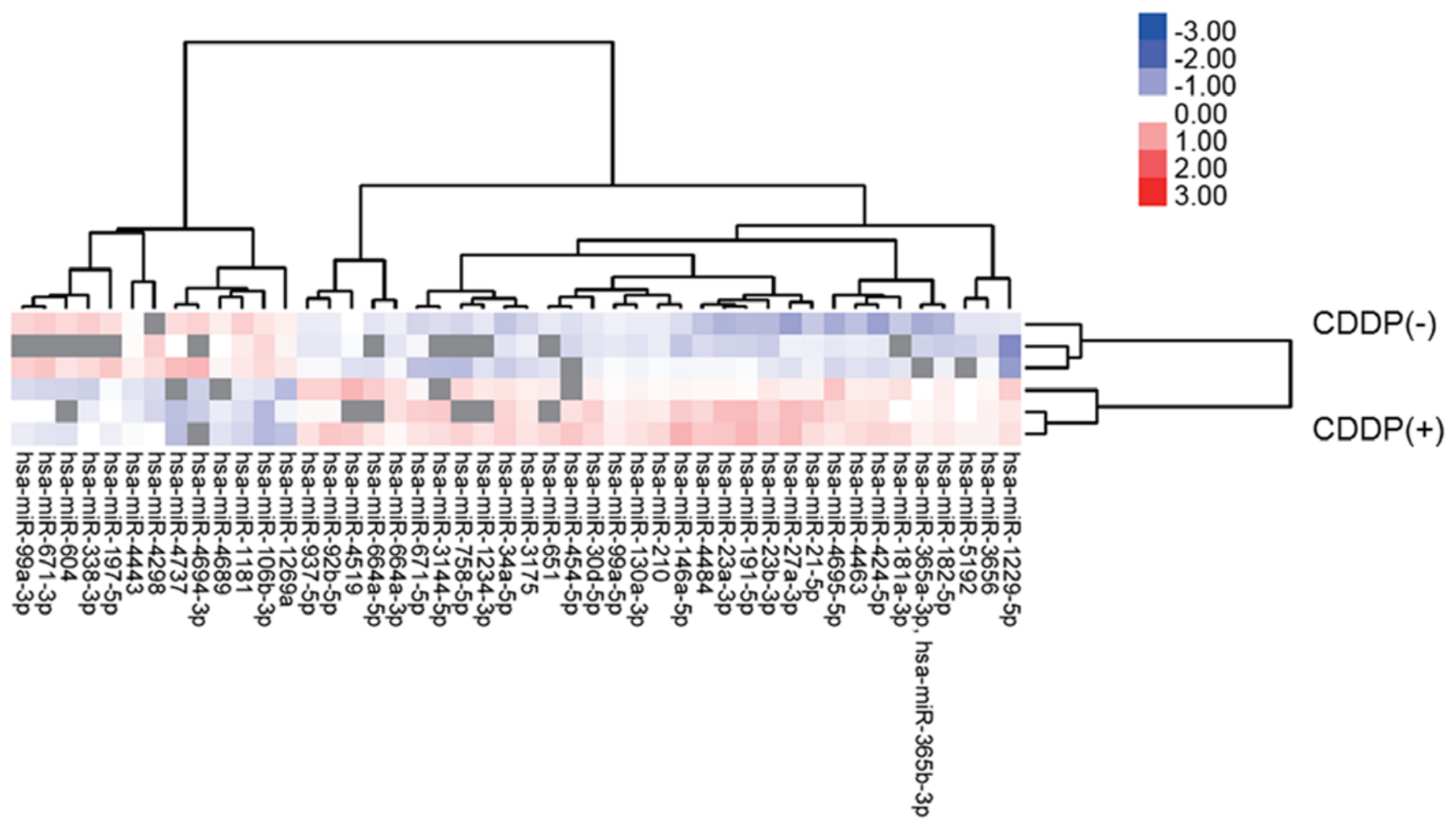

Figure 6. Hierarchical clustering of the $\mathrm{HuH7}$ cells that were treated with cisplatin and those that were untreated. HuH7 cells were clustered according to the expression profiles of 47 differentially expressed miRNAs between cisplatin-treated HuH7 cells and untreated HuH7 cells. The miRNA clustering tree is shown on the top, and the sample-clustering tree appears at the right. The color scale shown at the top illustrates the relative expression level of the miRNAs; red represents a high expression level while blue represents a low expression level.

First of all, the activation of IR induces the expression of IR substrates 1 and 2 (IRS1/2), which in turn mediate mitogenic and anti-apoptotic signaling (24). In addition, the overexpression of IRS1 prevents transforming growth factor $\beta 1$-induced apoptosis (25). In our present study, the phosphorylation of IR was inhibited by cisplatin according to the phosphorylated RTK array (Fig. 2B and C). Cisplatin also induced apoptosis (Fig. 5). These results suggest that IR signaling may be one of the important pathways that mediate cisplatin-induced apoptosis. Noteworthy, the phosphatase and tensin homolog (PTEN), which is one of the most important suppressors of the IR signaling pathway, was negatively regulated by microRNA-21 (16). Furthermore, microRNA-21 confers cisplatin resistance via the regulation of PTEN (26). This suggests that microRNA-21 may be induced in response to cisplatin during initial therapy, but that continuous treatment with cisplatin may induce the acquisition of resistance through the overexpression of microRNA-21. As shown in Table I, our data demonstrated the upregulation of microRNA-21 after the treatment of HCC cells with cisplatin. Therefore, microRNAs may modulate the IR signaling pathway during cisplatininduced apoptosis. 
Table I. Statistical results and chromosomal locations of the miRNAs that were upregulated in $\mathrm{HuH} 7$ cells that were treated with cisplatin.

\begin{tabular}{|c|c|c|c|}
\hline $\begin{array}{l}\text { Upregulated } \\
\text { miRNA }\end{array}$ & $\begin{array}{c}\text { Fold } \\
\text { (treated/ } \\
\text { non-treated) } \\
\text { mean } \pm \mathrm{SD}\end{array}$ & p-value & $\begin{array}{l}\text { Chromosomal } \\
\text { localization }\end{array}$ \\
\hline hsa-miR-1229-5p & $2.08 \pm 0.624$ & 0.028559 & 5 \\
\hline hsa-miR-1234-3p & 1.35 & 0.00523 & 8 \\
\hline hsa-miR-130a-3p & $1.25 \pm 0.077$ & 0.007693 & $11 \mathrm{q} 12.1$ \\
\hline hsa-miR-146a-5p & $1.69 \pm 0.377$ & 0.037223 & $5 q 34$ \\
\hline hsa-miR-181a-3p & 2.18 & 0.049811 & 1q32.1 \\
\hline hsa-miR-182-5p & $1.46 \pm 0.278$ & 0.030763 & $7 q 32.2$ \\
\hline hsa-miR-191-5p & $1.77 \pm 0.254$ & 0.047376 & $3 p 21.31$ \\
\hline hsa-miR-197-5p & 1.09 & 0.017823 & $1 \mathrm{p} 13.3$ \\
\hline hsa-miR-210 & $1.24 \pm 0.086$ & 0.041995 & $11 \mathrm{p} 15.5$ \\
\hline hsa-miR-21-5p & $1.47 \pm 0.132$ & 0.033956 & $17 q 23.1$ \\
\hline hsa-miR-23a-3p & $1.73 \pm 0.236$ & 0.036484 & $19 \mathrm{p} 13.13$ \\
\hline hsa-miR-23b-3p & $1.72 \pm 0.127$ & 0.008715 & $9 q 22.32$ \\
\hline hsa-miR-27a-3p & $1.85 \pm 0.222$ & 0.04843 & $19 \mathrm{p} 13.13$ \\
\hline hsa-miR-30d-5p & $1.39 \pm 0.160$ & 0.007856 & $8 \mathrm{q} 24.22$ \\
\hline hsa-miR-3144-5p & 1.78 & 0.047758 & 6 \\
\hline hsa-miR-3175 & $1.36 \pm 0.112$ & 0.004832 & 15 \\
\hline hsa-miR-338-3p & 1.00 & 0.039909 & $17 \mathrm{q} 25.3$ \\
\hline hsa-miR-34a-5p & $1.67 \pm 0.151$ & 0.002676 & $1 \mathrm{p} 36.22$ \\
\hline hsa-miR-3656 & $1.20 \pm 0.089$ & 0.01424 & 11 \\
\hline $\begin{array}{l}\text { hsa-miR-365a-3p, } \\
\text { hsa-miR-365b-3p }\end{array}$ & 2.35 & 0.02913 & $16 \mathrm{p} 13.12,17 \mathrm{q} 11.2$ \\
\hline hsa-miR-424-5p & $1.63 \pm 0.452$ & 0.04736 & Xq26.3 \\
\hline hsa-miR-4463 & $1.45 \pm 0.173$ & 0.015803 & 6 \\
\hline hsa-miR-4484 & $1.52 \pm 0.040$ & 0.037087 & 10 \\
\hline hsa-miR-4519 & $1.08 \pm 0.951$ & 0.014617 & 16 \\
\hline hsa-miR-454-5p & 1.62 & 0.038449 & $17 q 22$ \\
\hline hsa-miR-4695-5p & $1.73 \pm 0.665$ & 0.021036 & 1 \\
\hline hsa-miR-5192 & 1.88 & 0.028807 & 2 \\
\hline hsa-miR-651 & 1.37 & 0.044509 & $\mathrm{Xp} 22.31$ \\
\hline hsa-miR-664a-3p & $1.24 \pm 0.151$ & 0.017514 & 1 \\
\hline hsa-miR-664a-5p & 1.49 & 0.042349 & 1 \\
\hline hsa-miR-671-5p & $1.48 \pm 0.213$ & 0.033916 & 7q36.1 \\
\hline hsa-miR-758-5p & 1.83 & 0.024661 & $14 q 32.31$ \\
\hline hsa-miR-92b-5p & $1.38 \pm 0.180$ & 0.040637 & $1 q 22$ \\
\hline hsa-miR-937-5p & $1.30 \pm 0.166$ & 0.033649 & $8 \mathrm{q} 24.3$ \\
\hline hsa-miR-99a-3p & 1.03 & 0.015059 & $21 \mathrm{q} 21.1$ \\
\hline hsa-miR-99a-5p & $1.14 \pm 0.059$ & 0.028724 & $21 \mathrm{q} 21.1$ \\
\hline
\end{tabular}

In addition, cyclin D1 is regarded as one of the key molecules in the transition from G1 to S phase. On the one hand, the upregulation of cyclin D1 results in the rapid progression of HCC, on the other hand, cyclin D1 is downregulated by microRNA-338p $(27,28)$ in HCC cells. These microRNAs then induce G1 arrest (29) and promote cell apoptosis (30).
Table II. Statistical results and chromosomal locations of the miRNAs that were downregulated in $\mathrm{HuH7}$ cells that were treated with cisplatin.

\begin{tabular}{|c|c|c|c|}
\hline $\begin{array}{l}\text { Downregulated } \\
\text { miRNA }\end{array}$ & $\begin{array}{c}\text { Fold } \\
\text { (treated/ } \\
\text { non-treated) } \\
\text { mean } \pm \mathrm{SD}\end{array}$ & p-value & $\begin{array}{l}\text { Chromosomal } \\
\text { localization }\end{array}$ \\
\hline hsa-miR-106b-3p & $0.50 \pm 0.135$ & 0.00563 & $7 q 22.1$ \\
\hline hsa-miR-1181 & $0.70 \pm 0.042$ & 0.006913 & 19 \\
\hline hsa-miR-1269a & $0.69 \pm 0.170$ & 0.033337 & 4 \\
\hline hsa-miR-4298 & 1.00 & 0.030744 & 11 \\
\hline hsa-miR-4443 & $0.88 \pm 0.032$ & 0.041175 & 3 \\
\hline hsa-miR-4689 & $0.56 \pm 0.500$ & 0.024162 & 1 \\
\hline hsa-miR-4694-3p & 0.50 & 0.023221 & 11 \\
\hline hsa-miR-4737 & $0.35 \pm 0.337$ & 0.029994 & 17 \\
\hline hsa-miR-604 & 0.67 & 0.022309 & $10 p 11.23$ \\
\hline hsa-miR-671-3p & 0.93 & 0.014697 & 7q36.1 \\
\hline
\end{tabular}

In our study, cellular proliferation was significantly inhibited after cisplatin treatment in a dose-dependent manner (Fig. 1), and cyclin D1 expression was reduced at the protein level by cisplatin treatment (Fig. 4). Moreover, cisplatin induced apoptosis in these cells. Of note, microRNA-338 was significantly upregulated in cisplatin-treated HCC cells compared to non-treated HCC cells (Table I). This indicates that cisplatin inhibits the expression of cyclin D1 via the upregulation of microRNA-338-3p. Furthermore, the expression of microRNA-34a and microRNA-99a was also upregulated in HCC cells after treatment with cisplatin (Table I). Guo et al reported that microRNA-34a inhibits the potential for lymphatic metastasis by inducing the downregulation of cyclin D1 and Cdk6 (31). It was demonstrated that microRNA-99a suppresses the growth of hepatocellular carcinoma (HCC) via the induction of G1-phase cell cycle arrest and also correlates with patient survival (32). These data suggest that cisplatin inhibits cellular proliferation by modulating cell cycle regulatory molecules through microRNA-34a and microRNA-99a. MicroRNA-338-3p, microRNA-34a and microRNA-99a may be novel cell cycle regulators, and therefore, miRNA profiling may also be a powerful tool to discover targetable molecules in HCC.

In conclusion, microRNAs were strongly associated with the mechanisms of cisplatin-induced cell proliferation and apoptosis in HCC cells. Therefore, the analysis of microRNA profiles may be a powerful tool to elucidate new mechanisms of action of cisplatin and to discover new targetable molecules for the treatment of HCC.

\section{References}

1. Ferlay J, Shin HR, Bray F, Forman D, Mathers C and Parkin DM: Estimates of worldwide burden of cancer in 2008: GLOBOCAN 2008. Int J Cancer 127: 2893-2917, 2010.

2. Małkowski P, Pacholczyk M, Łagiewska B, Adadyński L, Wasiak D, Kwiatkowski A, Chmura A and Czerwiński J: Hepatocellular carcinoma - epidemiology and treatment. Przegl Epidemiol 60: 731-740, 2006 (In Polish). 
3. Belghiti J and Kianmanesh R: Surgical treatment of hepatocellular carcinoma. HPB Oxf 7: 42-49, 2005.

4. Lee PH, Lin WJ, Tsang YM, Hu RH, Sheu JC, Lai MY, Hsu HC, May W and Lee CS: Clinical management of recurrent hepatocellular carcinoma. Ann Surg 222: 670-676, 1995.

5. Rosenberg B, Vancamp L and Krigas T: Inhibition of cell division in Escherichia coli by electrolysis products from a platinum electrode. Nature 205: 698-699, 1965.

6. Galluzzi L, Senovilla L, Vitale I, Michels J, Martins I, Kepp O, Castedo M and Kroemer G: Molecular mechanisms of cisplatin resistance. Oncogene 31: 1869-1883, 2012.

7. Fuertes MA, Castilla J, Alonso C and Pérez JM: Cisplatin biochemical mechanism of action: From cytotoxicity to induction of cell death through interconnections between apoptotic and necrotic pathways. Curr Med Chem 10: 257-266, 2003.

8. Asechi H, Hatano E, Nitta T, Tada M, Iwaisako K, Tamaki N, Nagata H, Narita M, Yanagida A, Ikai I, et al: Resistance to cisplatin-induced apoptosis via PI3K-dependent survivin expression in a rat hepatoma cell line. Int J Oncol 37: 89-96, 2010

9. Drayton RM: The role of microRNA in the response to cisplatin treatment. Biochem Soc Trans 40: 821-825, 2012.

10. Masaki T: MicroRNA and hepatocellular carcinoma. Hepatol Res 39: 751-752, 2009.

11. Krek A, Grün D, Poy MN, Wolf R, Rosenberg L, Epstein EJ, MacMenamin P, da Piedade I, Gunsalus KC, Stoffel M, et al: Combinatorial microRNA target predictions. Nat Genet 37: 495-500, 2005

12. Calin GA, Dumitru CD, Shimizu M, Bichi R, Zupo S, Noch E, Aldler H, Rattan S, Keating M, Rai K, et al: Frequent deletions and down-regulation of micro-RNA genes miR15 and miR16 at 13 q14 in chronic lymphocytic leukemia. Proc Natl Acad Sci USA 99: $15524-15529,2002$.

13. Michael MZ, O'Connor SM, van Holst Pellekaan NG, Young GP and James RJ: Reduced accumulation of specific microRNAs in colorectal neoplasia. Mol Cancer Res 1: 882-891, 2003

14. Lee EJ, Gusev Y, Jiang J, Nuovo GJ, Lerner MR, Frankel WL, Morgan DL, Postier RG, Brackett DJ and Schmittgen TD: Expression profiling identifies microRNA signature in pancreatic cancer. Int J Cancer 120: 1046-1054, 2007.

15. Takamizawa J, Konishi H, Yanagisawa K, Tomida S, Osada H, Endoh H, Harano T, Yatabe Y, Nagino M, Nimura Y, et al: Reduced expression of the let-7 microRNAs in human lung cancers in association with shortened postoperative survival. Cancer Res 64: 3753-3756, 2004.

16. Meng F, Henson R, Wehbe-Janek H, Ghoshal K, Jacob ST and Patel T: MicroRNA-21 regulates expression of the PTEN tumor suppressor gene in human hepatocellular cancer. Gastroenterology 133: 647-658, 2007.

17. Gramantieri L, Ferracin M, Fornari F, Veronese A, Sabbioni S, Liu CG, Calin GA, Giovannini C, Ferrazzi E, Grazi GL, et al: Cyclin G1 is a target of miR-122a, a microRNA frequently downregulated in human hepatocellular carcinoma. Cancer Res 67: 6092-6099, 2007.

18. Wong QW, Lung RW, Law PT, Lai PB, Chan KY, To KF and Wong N: MicroRNA-223 is commonly repressed in hepatocellular carcinoma and potentiates expression of Stathmin1. Gastroenterology 135: 257-269, 2008.
19. Varnholt H, Drebber U, Schulze F, Wedemeyer I, Schirmacher P, Dienes HP and Odenthal M: MicroRNA gene expression profile of hepatitis C virus-associated hepatocellular carcinoma. Hepatology 47: 1223-1232, 2008.

20. Masaki T, Tokuda M, Yoshida S, Nakai S, Morishita A, Uchida N, Funaki T, Kita Y, Funakoshi F, Nonomura T, et al: Comparison study of the expressions of myristoylated alanine-rich $\mathrm{C}$ kinase substrate in hepatocellular carcinoma, liver cirrhosis, chronic hepatitis, and normal liver. Int J Oncol 26: 661-671, 2005.

21. Bradford MM: A rapid and sensitive method for the quantitation of microgram quantities of protein utilizing the principle of protein-dye binding. Anal Biochem 72: 248-254, 1976.

22. Laemmli UK: Cleavage of structural proteins during the assembly of the head of bacteriophage T4. Nature 227: 680-685, 1970.

23. Towbin H, Staehelin T and Gordon J: Electrophoretic transfer of proteins from polyacrylamide gels to nitrocellulose sheets: Procedure and some applications. Proc Natl Acad Sci USA 76: 4350-4354, 1979.

24. Reuveni H, Flashner-Abramson E, Steiner L, Makedonski K, Song R, Shir A,Herlyn M, Bar-Eli M and Levitzki A: Therapeutic destruction of insulin receptor substrates for cancer treatment. Cancer Res 73: 4383-4394, 2013.

25. Tanaka S and Wands JR: Insulin receptor substrate 1 overexpression in human hepatocellular carcinoma cells prevents transforming growth factor beta1-induced apoptosis. Cancer Res 56: 3391-3394, 1996.

26. Yang SM, Huang C, Li XF, Yu MZ, He Y and Li J: miR-21 confers cisplatin resistance in gastric cancer cells by regulating PTEN. Toxicology 306: 162-168, 2013.

27. Fu X, Tan D, Hou Z, Hu Z and Liu G: miR-338-3p is downregulated by hepatitis $B$ virus $X$ and inhibits cell proliferation by targeting the 3'-UTR region of cyclinD1. Int J Mol Sci 13: 8514-8539, 2012

28. Fu X, Tan D, Hou Z, Hu Z, Liu G, Ouyang Y and Liu F: The effect of miR-338-3p on HBx deletion-mutant (HBx-d382) mediated liver-cell proliferation through CyclinD1 regulation. PLoS One 7: e43204, 2012.

29. Chen L, Zheng J, Zhang Y, Yang L, Wang J, Ni J, Cui D, Yu C and Cai Z: Tumor-specific expression of microRNA-26a suppresses human hepatocellular carcinoma growth via cyclin-dependent and -independent pathways. Mol Ther 19: 1521-1528, 2011.

30. Yang X, Liang L, Zhang XF, Jia HL, Qin Y, Zhu XC, Gao XM, Qiao P, Zheng Y, Sheng YY, et al: MicroRNA-26a suppresses tumor growth and metastasis of human hepatocellular carcinoma by targeting interleukin-6-Stat3 pathway. Hepatology 58: 158-170, 2013.

31. Guo Y, Li S, Qu J, Wang S, Dang Y, Fan J, Yu S and Zhang J: MiR-34a inhibits lymphatic metastasis potential of mouse hepatoma cells. Mol Cell Biochem 354: 275-282, 2011.

32. Li D, Liu X, Lin L, Hou J, Li N, Wang C, Wang P, Zhang Q, Zhang P, Zhou W, et al: MicroRNA-99a inhibits hepatocellular carcinoma growth and correlates with prognosis of patients with hepatocellular carcinoma. J Biol Chem 286: 36677-36685, 2011. 